John Carroll University

Carroll Collected

Sociology

$5-2015$

\title{
Gender Differentiation in Paid and Unpaid Work during the Transition to Parenthood
}

Medora W. Barnes

John Carroll University, mbarnes@jcu.edu

Follow this and additional works at: http://collected.jcu.edu/soc-facpub

Part of the Family, Life Course, and Society Commons, and the Gender and Sexuality Commons

\section{Recommended Citation}

Barnes, Medora W., "Gender Differentiation in Paid and Unpaid Work during the Transition to Parenthood" (2015). Sociology. 24.

http://collected.jcu.edu/soc-facpub/24

This Article is brought to you for free and open access by Carroll Collected. It has been accepted for inclusion in Sociology by an authorized administrator of Carroll Collected. For more information, please contact connell@jcu.edu. 


\title{
Gender Differentiation in Paid and Unpaid Work during the Transition to Parenthood
}

\author{
Medora W. Barnes* \\ Department of Sociology, John Carroll University
}

\begin{abstract}
The transition to parenthood may be especially difficult because relationships need to be largely reorganized to meet demanding new challenges. For scholars interested in gender inequality, the transition to parenthood is a critical time in which gender differentiation is generated by both economic and cultural forces. Although newly married childless couples tend to share both paid and unpaid labor rather equally, when men and women become parents, their patterns become increasingly differentiated by gender. Cultural beliefs that emphasize mothers as the primary parent and fathers as secondary reinforce unequal patterns in housework and childcare. Time availability models, bargaining perspectives, and gender theories all have been used to explain these patterns. Some changes that could help ease the transition to parenthood include expanding US parental leave policies, improving available childcare, adding flexible work policies, and offering more couples-focused intervention programs. Although much is known about the topic, more research is needed for the literature to reflect the new generation of global and diverse parents.
\end{abstract}

It's not just that couples are startled by how the division of labor falls along gender lines, but they describe the change as if it were a mysterious virus they picked up when they were in the hospital having their baby; they don't seem to view their arrangements as choices they have made. (Cowan and Cowan 1992, 98)

\section{Introduction}

Scholars have argued that transitions are times of vulnerability, and the transition to parenthood may be especially difficult because relationships need to be largely reorganized to meet demanding new challenges (Baxter et al. 2008; Cowan and Cowan 1992; Cox et al. 1999; Fox 2009; LaRossa and LaRossa 1981). Due to its transformative effects, this time period frequently defined as pregnancy through the first year of parenthood - has become one of the most studied life transitions. Scholars emphasize how a child's birth is a demanding life situation that alters the division of labor and influences how men and women feel about themselves, their lives, and their intimate relationships.

Couples are influenced in different ways by the transition to parenthood depending on their social characteristics, psychological traits, and relationship quality; therefore, the goal of much contemporary literature is to determine which couples will be the most vulnerable to negative influences (Cowan and Cowan 1992; Fox 2009; Goldberg et al. 2012; Kluwer 2010). Overall, research generally focuses on four aspects: (1) changes in relationship satisfaction and/or conflict, (2) changes in individual identities, (3) social and workplace policies, and/or (4) changes in the gendered division of labor.

These four topics are not unrelated. For example, an increasingly traditional division of

household labor can increase perceptions of unfairness, increase conflict, and lead to 
relationship satisfaction for both partners (Dew and Bradford Wilcox 2011; Keizer and Schenk 2012; Kluwer et al. 1996; Steil 1997). Generally, more of the research focusing solely on marital conflict and relationship satisfaction comes from psychology and family studies, while studies examining the division of labor and/or policy are frequently drawn from sociology, economics, and gender studies.

As literature in all areas is immense, this review largely emphasizes the fourth aspect and discusses the others only as they are interrelated. It focuses on the often inadvertent ways that gender differentiation and inequality tend to be reproduced during the transition to parenthood through changes in paid and unpaid work. It focuses mostly on heterosexual couples, as the gendered division of labor within families is of interest. For many years, researchers tended to study mostly heterosexual, married, middle-class couples having their first child with an unstated assumption that similar processes were occurring in families of other types (Meteyer and Perry-Jenkins 2010). Contemporary scholars have been more attentive to issues of diversity in families; however, the majority of research still focuses on non-poor, heterosexual couples. This review begins by addressing why gender differentiation is significant and offers brief summaries of common theoretical explanations. It next describes key patterns found in empirical research about paid and unpaid labor during this time period. Then a few changes are highlighted that could help ameliorate problems during the transition to parenthood. Lastly, suggestions are also made for future research.

\section{Why does gender differentiation matter?}

The transition to parenthood is seen as a critical time in which gender inequality is reinforced by both economic and cultural forces, which "are generated in part by the social construction of mothers as essential and fathers as relatively peripheral to babies" (Walzer 1998, 14). Although newly married childless couples share paid and unpaid labor fairly equally (Baxter et al. 2008), when people become parents their work and family behaviors become increasingly differentiated by gender (Belsky and Kelly 1994; Bianchi et al. 2000; Cowan and Cowan 1992; Walzer 1998). According to some researchers, the majority of young men and women now prefer to share both work and family roles within their household (Galinsky et al. 2009; Parker and Wang 2013); however, cultural messages concerning how much housework and childcare men and women should be doing are often powerful and conflicting (Sanchez and Thomson 1997; Walzer 1998). Furthermore, workplaces are often not set up to accommodate caregiving (Fried 1998; Stone 2007; Williams 1999).

Gender differentiation in labor is a concern for the broader society when it leads to women and men carrying unequal workloads. Twenty-five years ago, Arlie Hochschild (1989) brought attention to the "second shift" of unpaid work that employed women did at home. She estimated that including unpaid domestic labor, dual-earner mothers in the 1960s and 1970s worked on average 15 hours longer each week than their husbands. This left them less leisure time, less time for sleeping, and overall more pressed for time (Hochschild 1989). She argued that society was experiencing a "stalled revolution" where women had begun to work more hours in paid employment, yet men had not increased their hours in domestic labor to the same extent. Whether our society is still experiencing this "stalled revolution" is a matter of much debate (Latshaw 2011; Milkie et al. 2009; Schor 1991; Wharton 2012).

Recently, researchers found no statistical difference in the number of hours the average mother and father (regardless of employment status) work each week, when paid and unpaid hours are added together (Milkie et al. 2009; Parker and Wang 2013). Nevertheless, as work-family scholars remind us, averages such as these that collapse employment categories, paid and unpaid work, and ages of children, can often disguise important differences 
(Jacobs and Gerson 2004). Mothers of young children who work full time and have fully employed spouses appear to have the longest average work weeks of 73 total hours (37 paid work, 15 childcare, and 21 other domestic labor) (Milkie et al. 2009). They work five more hours a week $(20 \mathrm{~h} /$ month) than similarly situated fathers, who work $68 \mathrm{~h}$ on average (46 paid work, 9 childcare, and 15 other domestic labor) (Milkie et al. 2009). Differences in paid and unpaid hours are evident also, as these "fully employed" mothers worked $7 \mathrm{~h}$ less for pay on average than fathers, while doing 15 more hours of unpaid labor (36 compared to 21). Non-employed parents have the shortest overall work weeks. When only the father works, their non-employed partner works $11 \mathrm{~h}$ less on average; when only the mother is employed, their partner works $25 \mathrm{~h}$ less (Parker and Wang 2013), suggesting that non-employed fathers do less domestic labor, even though their spouses are working full time.

In addition to concerns about inequality in overall workloads, there are concerns about the long-term economic consequences for women who do more unpaid labor and less paid labor (Hook 2010). The wage gap between mothers and women without children has been widening, and some scholars see motherhood as a key factor in the lingering gender wage gap (England 2005; Waldfogel 1998). This gap emerges for many reasons, varying by income, race, and family situation (Budig and Hodges 2010; Gough and Noonan 2013; Parrott 2014; Waldfogel 1998). Some women are forced to temporarily leave their jobs over inadequate maternity leave and, consequently, may lose job seniority. Other women scale back to part-time work to manage unequally divided domestic responsibilities and end up losing salary and benefits. Some full-time workers are unwillingly thrust on the "mommy track," if no longer perceived as committed or competent (Correll et al. 2007). When facing these difficulties, some women "opt out" of the labor force entirely and then find it difficult to re-enter a career when their children are older (Stone 2007). Employer discrimination and selective hiring away from mothers are also believed to play a role (Correll et al. 2007; Gough and Noonan 2013). Overall, this "motherhood wage gap" and the way gender differentiation reinforces it often result in higher rates of poverty for women and stagnation in achieving gender equality.

When mothers perform high amounts of unpaid childcare and housework, problems are not simply limited to economic consequences from a wage penalty. Spending one's days engaged in unpaid household labor can be socially isolating, can be stressful, and is associated with a higher likelihood of a woman experiencing depression, especially if she perceives the division of labor as unfair (Glass and Fujimoto 1994; Taylor 1996). Furthermore, it is associated with low bargaining power within their relationship. When women quit their jobs, they are especially vulnerable and dependent on their spouse and less able to get them to help with household work (Milkie 2011).

The patterns of gender differentiation that develop during the transition to parenthood have long-term consequences, as research shows that they can lay the foundation for parents' longterm patterns of childcare and household labor (Gornick and Meyers 2009; Hook 2010; Kotsadam and Finseraas 2011; Pleck 1993). Once everyday family patterns are organized around gender, it appears hard to entirely "un-do" these configurations, as long as there remain significant amounts of childcare and housework that still need to be done. By the time children are grown, mothers and fathers often find themselves in unequal positions in regard to the paid labor market, and the reproduction of gender inequality continues.

\section{Explaining gender differentiation in labor patterns}

There are many explanations as to why the majority of heterosexual couples continue to have a gendered division of labor. Theories include those based on biology, personality, socialization, economics, and the desire for efficiency/specialization (Becker 1981; Chodorow 1978; 
Hochschild 1983; Parsons and Bales 1955). While there is no space to review them all, a few deserve particular attention as they dominate contemporary research and have important implications for the transition to parenthood.

Time availability (or time allocation) perspectives examine how much time individuals commit to tasks besides unpaid labor. They theorize that the division of housework reflects competing demands and the rational calculation of who has the time available to do it (Coverman 1985). Scholars frequently examine parents' employment status, hours of paid work, work schedules, and the number of children in the household. Studies find that, for both men and women, longer hours spent in paid employment are linked to less time spent on domestic work during the transition to parenthood (Baxter et al. 2008; Bianchi et al. 2000). Those men and women who are not employed spend more time doing housework than those employed either full or part time (Bianchi et al. 2000). In couples, employed men whose wives also work full time are likely to do more housework and childcare than those with wives who work less in the paid labor market (Sanchez and Thomson 1997), especially when they work different schedules than their wives (Brayfield 1995; Glass 1998; Meteyer and Perry-Jenkins 2010). Qualitative studies of lesbian couples have also offered some confirmation for time availability theories, as greater hours in paid work are often associated with lower levels of involvement in family work (Goldberg and Perry-Jenkins 2007; Reimann 1997).

Exchange (or "bargaining") perspectives highlight how access to different "relative resources" can be important in determining power differentials within households. When husbands and wives contribute different levels of economic resources to the household, they will have more or less bargaining power over how domestic labor is allocated (Brines 1993; Milkie 2011). Theoretically, spouses with small differences between their earnings should share domestic labor more equally (Coltrane 2000; Sayer 2005). Among new mothers, how much income they make, the proportion of income contributed to the household, and the prestige of their job all influence their bargaining power in getting their spouse or partner to help with domestic work (Baxter et al. 2008; Milkie 2011). The proportion of income that a father contributes to the household is thought to influence how much housework they do (Baxter et al. 2008), although not all studies have found that it predicts involvement as well as might be expected (Brines 1993; Deutsch et al. 1993).

Exchanges of resources between men and women may play a larger role in explaining the distribution of housework among White couples than among those of other racial-ethnic groups. For example, the number of hours of housework done by Black men is associated with how much he earns relative to his wife; however, Black women appear to do less housework than other groups of women regardless of whether they are in a weak or strong economic position to bargain out of it (Wight et al 2013). Among Asian couples, there does not appear to be any association between the relative earnings of the couple and the amount of housework the husband does; however, as Asian women earn more, their time spent doing housework tends to go down (Wight et al 2013).

An additional factor to consider is that high-income individuals or couples may avoid spending time doing housework by outsourcing housework to third parties (de Ruijter et al. 2005; Fox 2009). Because this perspective assumes that domestic labor is an unpleasant activity that partners "bargain" to avoid, it may help explain the division of housework better than the division of childcare, which parents are more likely to enjoy and less likely to want to avoid (Bianchi et al. 2012; Raley et al. 2012).

Scholars have used several related perspectives when examining the influence of gender on the transition to parenthood. A considerable number of studies have looked at how an individual's gender ideologies affect their division of household labor. Scholars have generally found that women with egalitarian gender ideologies do fewer hours of housework 
(Baxter et al. 2008; Beitel and Parke 1998; Sanchez and Thomson 1997). In contrast, findings about men are less consistent, with some scholars finding that men with egalitarian gender attitudes do more hours of housework (Baxter et al. 2008; Gaunt 2006) and others finding no increase (Bianchi et al. 2000). Meteyer and Perry-Jenkins (2010) found that gender ideologies affected couples' initial division of labor after birth; however, mothers' employment status (full versus part time) had a larger impact over time.

Scholars also use what is called a "doing gender" or "gender display" framework. This perspective suggests that housework is not necessarily allocated rationally, but instead cultural norms and individual beliefs about gender affect the amount and type of housework an individual does. Extending Goffman's (1977) concept of gender display, West and Zimmerman (1987) emphasize how men and women continuously "do" gender in interaction through trying to live up to the society's gender expectations. Their behaviors are always held accountable to their perceived sex category and may be censured if they attempt to act in ways that go against dominant norms for masculinity and femininity. Household labor is symbolically constructed as "women's work" (not men's) and emerges as a way for women to simultaneously perform gender and display love for their family (Coltrane 1989; DeVault 1991).

Gender theories of interaction may be especially useful in explaining the increased gender differentiation during the transition to parenthood, due to the strong connections between gender and mothering/fathering. Scholars have suggested that people "do" parenthood in the same ways that people "do" gender, in that they are defined through social interaction (Garey 1999; Walzer 1998). When new mothers attempt to enact the role of "mother," they may do a larger share of the carework because they view this as part of a mother's responsibility in fulfilling "intensive motherhood" ideals. The cultural ideals of intensive mothering expect women to be uniquely responsible, intensely devoted, and constantly attuned to their child's emotional, physical, and educational needs (Doucet 2006; Hays 1996). Because women are held more accountable for having a clean house and presentable children than men, this helps explain some women's reluctance to give up primary control of these tasks and can lead to maternal gatekeeping (Allen and Hawkins 1999; Ehrensaft 1990; Gaunt 2008).

How a woman attempts to enact the role of mother may be influenced by her race and social class. The social and economic resources available to a woman greatly affect her ability to live up to intensive mothering ideals (Fox 2009; Hays 1996; Lareau 2003; Nelson 2010). One explanation for why White women on average do more hours of household labor than Black women are these incredibly high (and sometimes unattainable) standards of motherhood and associated household cleanliness that are part of the social construction of intensive mothering, as well as White middle-class motherhood (Parrott 2014; Wight et al. 2013). Historically, such high domestic expectations would have been especially unrealistic for Black mothers who traditionally had to balance motherhood with paid employment (Parrott 2014).

Scholars utilizing gender theories have also emphasized how structural constraints and opportunities shape the context in which men and women make decisions. Parenting takes place within broad systems of power and social institutions (employers, federal/state policies, and schools) that encourage behaviors aligned with traditional gender roles (Ferree 1990). The policies of the United States continue to reflect the belief that childcare is the private responsibility of the child's parents (unless they put their child at risk), instead of a public responsibility. Although in recent years, the government has enacted the Federal Telework Act, increased the availability of subsidized preschool in some areas, and begun to focus more attention on the importance of paid leave; these few federal initiatives are insufficient. Parents remain under pressure to develop efficient childcare arrangements without the flexible policies that would make this more easily achievable (Clawson and Gerstel 2007; Gornick and Meyers 2009; Stone 2007). 
Mothers continue to be seen within society as essential to the well-being of children and ultimately held responsible for the children and home, while fathers are often viewed as secondary and optional (Fox 2009; Walzer 1998). Therefore, this privatization ends up gendered, as men have a "choice" about whether to do childcare and how much to do, while most women end up with very little choice (Fox 2009). Stone (2007) argues that educated women in high-achieving jobs can be caught in a "double bind" between ideal motherhood norms and ideal worker norms, where their "options are indeed much more limited than they appear at first or than the women themselves appreciate" (p. 112). While these high-achieving women may end up feeling pushed out of the labor market, opting out of paid employment is not a financial option for most low- and middle-income women who have to negotiate childcare in other ways (Stone 2007).

\section{Empirical research on changes in paid and unpaid labor}

\section{Method considerations}

Before reviewing specific patterns in paid and unpaid work during the transition to parenthood, it is important to understand how researchers collect these data. The two most common methods are using (1) survey or interview questions that ask respondents to estimate the time they spend on tasks in a "usual day" or in the past day and (2) time diaries/time use surveys, where people are asked about their primary and secondary activities sequentially (including starting and ending times) over a specific time period (usually $24 \mathrm{~h}$ ). Of these two methods, the validity and reliability of time diary estimates are thought to be higher than those obtained through standard surveys (Robinson and Godbey 1999). Another less common technique is the experience sampling method, where respondents wear beepers and when it goes off, they record both their activities and feelings. This has the advantage of systematically collecting real-time data on people's activities and emotions; however, due to issues of feasibility, it may be more difficult to use with large representative samples (Milkie et al. 2009).

Variation in several other methodological issues can be found within the literature as well. Quantitative research tends to be cross-sectional, although there are a handful of high-quality longitudinal studies. Recently, more (although not all) qualitative studies have tended to be longitudinal (Fox 2009; Keizer and Schenk 2012; Kluwer 2010; Sanchez and Thomson 1997). This is partly because patterns are often initially established quantitatively and then explored more deeply qualitatively. Longitudinal research has the advantage of allowing scholars to incorporate the variety of changes that new parents experience throughout the time period. There is also variation in the unit of analysis within the studies, as some studies focus on individuals, while others insist that a dyadic perspective is necessary in which the couple is the unit of analysis (Keizer and Schenk 2012). Recently, a few scholars have begun to incorporate childless couples into their studies to use as a control (Dew and Bradford Wilcox 2011; Keizer and Schenk 2012). Comparing new parents' behaviors with those of couples without children is thought to be one of the best ways to understand the changes that having a child creates in a person's life (Milkie 2011).

\section{Changes in paid work patterns}

The entrance of the majority of mothers into the paid labor force was one of the largest transformations of the family in the United States in the last century (Bianchi et al. 2000; Jacob and Gerson 2004). According to Census Bureau data, in the early 1960s, only 14\% of mothers were working 6 months post-partum, and 17\% were working a year after having their 
first child. By the mid-2000s, 57\% of mothers were working 6 months post-partum, and 63\% were working 12 months post-partum (Laughlin 2011). Although the increase is striking, approximately $40 \%$ of mothers of young children are currently not employed, and only one-third of mothers of preschoolers work full time (Milkie et al. 2009). Currently, only 16\% of adults say that mothers working full time is the "ideal situation" for young children, and 42\% say mothers working part time is ideal (Parker and Wang 2013), which illustrates that there is continuing societal ambivalence about women's work.

The majority of research on paid work patterns of heterosexual couples during the transition to parenthood has found that after the birth of a baby, men tend to do more paid work while women do less (Bianchi et al. 2000; Cowan and Cowan 1992; Sanchez and Thomson 1997). In addition, with each subsequent birth, the average number of hours a women works appears to goes down (Sanchez and Thomson 1997; Upton 2000), and she is less likely to be in the paid labor force at all (Cohany and Sok 2007). When comparing married mothers of infants in 2005 , those women with just one child had a labor force participation rate of 60 percent, those with two children had a rate of 55 percent, and those with three children had a rate of 46 percent (Cohany and Sok 2007). Limiting women's hours of paid employment is arguably the most influential decision couples make concerning how the division of household labor will ultimately change during the transition to parenthood (Meteyer and Perry-Jenkins 2010; Sanchez and Thomson 1997).

Concerning father's work hours, some scholars found that men with children work more hours than men without children (Jacobs and Gerson 2004); others found that men's work is largely unaffected by having a child (Sanchez and Thomson 1997) or by the child's age (Milkie et al. 2009). Sanchez and Thomson (1997) argue that men's work patterns stay stable with the birth of one child, but when men have two or more children, their time in paid labor goes up by $3 \mathrm{~h} /$ week. Men who increase their working hours may be responding to the added economic expenses associated with raising children. There is also some suggestion that among recent cohorts of younger men, fatherhood reduced work involvement for men who hold egalitarian gender views but increased it for those who adhere to traditional ideologies (Kaufman and Uhlenberg 2000). Although heterosexual fathers' paid work patterns may change during the transition to parenthood, they generally do not change as much as mothers' work hours (Sanchez and Thomson 1997; Walzer 1998).

Understanding changes in paid work patterns involves understanding the interplay of a variety of characteristics. There appear to be racial variations in these patterns, as there are indications that average hours of paid work may go up for African-American mothers (Dew and Bradford Wilcox 2011). This may be because Black women's participation in the labor force is the most similar to men's relative to other racial-ethnic groups (Bureau of Labor Statistics 2011). Married Black women have a long history of higher paid labor force participation, which is unique when compared with the lower rates of White, Asian, or Hispanic women (Cohany and Sok 2007; Wight et al. 2013). These patterns also may be different among lesbian couples, where a study based on longitudinal interviews found that both biological and non-biological co-mothers tended to decrease their hours in paid work during the transition to parenthood, with biological mothers showing a slightly larger decrease (Goldberg and Perry-Jenkins 2007).

\section{Changes in unpaid labor: housework and childcare}

Though married women generally do more unpaid labor than unmarried cohabiting women, the patterns become even more differentiated with the arrival of the first child (Baxter et al. 2008; 
Bianchi et al. 2000; Davis et al. 2007). "Unpaid labor" is conceptualized as "unpaid work done to maintain family members and/or a home" (Shelton and John 1996, 30). Until recently, studies of unpaid labor tended to focus mainly on housework (cooking, cleaning, laundry, and shopping). Lately, there has been more attention paid to concurrently studying childcare and the emotional or mental labor that may be the most challenging part of domestic labor (Bianchi et al. 2012; Bonnar 1991; Coltrane 2000; Hochschild 1989; Walzer 1998), although it may be important to treat them separately, theoretically and analytically (Sullivan 2013). Some research also examines the specific types of housework that men and women do, as some are more time inflexible and discretionary than others (Coltrane 2000; Hook 2010). Studying housework in isolation does not allow scholars to truly understand a couple's time allocation or division of labor.

The majority of scholars have found significant increases in the number of hours the average woman spends in housework over the transition to parenthood (Baxter et al. 2008; Cowan and Cowan 1992; Parrott 2014; Sanchez and Thomson 1997; Wight et al. 2013), with only Gjerdingen and Center (2004) finding no difference. This general pattern contrasts with men, where the majority of studies found that most fathers do not significantly increase housework hours with the addition of a child (Gjerdingen and Center 2004; Sanchez and Thomson 1997; Wight et al. 2013). Some studies found that men decrease their time spent in housework with the birth of either their first child (Kluwer et al. 2002) or a subsequent child (Baxter et al. 2008). This is a significant finding because when a child is born, the hours of necessary housework increase (e.g., laundry, cleaning, and shopping). On average, mothers of young children do twice as much housework as men (Milkie et al. 2009), although many factors affect this division including the parents' educational levels, ages when the first child is born, age gap between the parents, quality of couples' relationship, and the child's gender (Bianchi et al. 2000; Coltrane 1996; Deutsch et al. 1993; Helms-Erikson 2001; Sanchez and Thomson 1997). There are also racial differences with White men's housework time being high and Asian and Hispanic men being low relative to other groups of men (Parrott 2014; Wight et al. 2013). Black men do an average amount of housework relative to other men, but because Black women do considerably less housework on average than other groups of women, the gender gap in total housework time is smallest among Blacks (Sayer and Fine 2011; Wight et al. 2013).

Although housework is an essential component of domestic labor and significant when examining gender equity, it has been argued that childcare is even more important to study (Bianchi et al. 2012; Oliker 2011). Some types of housework (albeit not all) can at least temporarily be left undone or can be fit in around parents' work schedules. Therefore, gender differences in time spent in childcare and cultural ideas about who is responsible for children may be one of the key forces holding back gender equality (Bianchi et al. 2012; Hays 1996; Walzer 1998). Although total hours spent performing housework has declined over the last several decades, time spent doing childcare has increased for both women and men. Even those mothers today who work full time for pay spend more time doing direct childcare than the average mother in the 1950s, when less than $20 \%$ of married mothers were in the paid labor force (Bianchi et al. 2000, 2012; Cohany and Sok 2007). The gender gap in childcare has consistently declined as fathers have devoted more hours to childcare, yet mothers still do about 50\% more childcare than fathers (Milkie et al. 2009). In many households, a "manager-helper" dynamic still appears to exist with fathers taking a secondary role (Allen and Hawkins 1999; Coltrane 1996; Gerson 1993; Hochschild 1989; LaRossa and LaRossa 1989). There is also some indication that men may be more likely to participate in those aspects of childcare they view as "fun" (Coltrane 1996) or in public fathering activities (Shows and Gerstel 2009). In contrast, women still tend to be in charge of the "invisible" mental and emotional labor such as worrying, 
processing information, and managing the division of labor, which are indicative of their having primary responsibility for the children (DeVault 1991; Fox 2009; Walzer 1998).

Research done among lesbian and gay couples generally indicates that same-sex couples have a more equal division of household labor than heterosexual couples (Dunne 2000; Goldberg et al. 2012). Where inequality does exist, it tends to center around one partner spending more hours in paid work and doing less unpaid family work (Carrington 1999; Goldberg and Perry-Jenkins 2007; Goldberg et al. 2012). Currently, more research has been done on the division of labor among lesbian couples during the transition to parenthood than among gay men. Among lesbian couples, research has included both those that became mothers through donor insemination and by adoption, as whether one is biologically related to the baby has been examined as a key variable in the division of domestic labor (Goldberg and Perry-Jenkins 2007; Goldberg et al. 2012). One qualitative study of lesbian couples using unknown donors found that couples divided housework quite equally; however, biological mothers tended to contribute more to childcare (Goldberg and Perry-Jenkins 2007). Other studies of the importance of biological ties have been mixed. Reimann (1997) used retrospective qualitative data and described small differences based on biology in lesbians' division of labor in the first few months following birth; however, she argued that these biological effects were usually short-lived and rarely resulted in long-term specialization into homemaker and breadwinner roles. In Dunne's (2000) study of British lesbian couples using known donors, she argues that the high value that lesbian co-mothers attach to nurturing together and being fair to one another overrides other considerations and leads to a more equal division of labor.

\section{What could be done to ease the transition?}

It is impossible to discuss here all the societal changes that could help facilitate gender equality among new parents; however, the lack of paid parental leave in the United States deserves special scrutiny. Since the passage of the Family Medical Leave Act (FMLA) in 1993, both men and women can take up to 12 weeks of job-protected parental leave if they meet certain employment criteria $^{1}$ (see Armenia et al. 2014 for analysis of compliance rates). The leave is unpaid except for in a handful of states that have recently passed programs providing partial reimbursement. ${ }^{2}$ Individual workplace policies may also offer paid leaves or allow workers to apply paid vacation days, sick days, or personal days toward a parental leave. When only unpaid leave is available, usually only one parent (if any) takes a leave, and it is most often the mother. In addition to the mother's biological recovery, this is due to what Risman (1998) calls the "logic of gendered choices" (p. 29). Even in couples without a preference for a traditional division of labor, the economic opportunity costs for a woman's time at home are still often lower than for her partner due to the gender wage gap. Subsequently, when a mother stays at home with a newborn for several weeks and a father takes only a few days off, it is easy for unequal parenting patterns to form and feel "natural" (Walzer 1998).

The short length (compared to the several months or more available in many Western nations) and relatively rigid structure of US parental leave can lead mothers to quit their jobs rather than put an infant in paid childcare. If children are born with health difficulties (temporary difficulties related to pre-term births are especially common), mothers can easily use up the 12 weeks allowed under the FMLA and be forced out of paid work regardless of their childcare intentions. Although very long periods of supported leave can lead to negative work outcomes for women and increase gender inequality (Gornick 2000; Hartmann and Lovell 2009; Waldfogel 2001), such a short unpaid leave forces families to make difficult decisions concerning paid work, which can lead to greater gender differentiation. Additionally, US women don't usually have the option of combining part-time employment with part-time 
leave over several months, which may be especially helpful for mothers experiencing the birth of a second or subsequent child (Barnes 2013). These types of policies have already been introduced in some European countries (e.g., France, Germany, Portugal, and Sweden; Moss and Deven 2006).

A 5- to 6-month parental leave that covered more US workers and provided for income reimbursement would help reduce gender differentiation in paid work through encouraging new mothers' continued attachment to the labor force (Gornick and Meyers 2009; Hartmann and Lovell 2009; Hofferth 1996; Joesch 1997; O’Brien 2013). Not surprisingly, when researchers study country-level data, those countries with more supportive policies for mothers, including paid leave (such as Finland, Denmark, or Sweden), have the smallest difference in employment rates between mothers of young children and those of older children (Gornick et al. 1998). Research suggests that family-supportive policies such as paid maternity leave, direct childcare subsidies, and the availability of universal pre-kindergarten education may help reduce the gender wage gap in the United States (Waldfogel 1998). Black and Hispanic women may need additional policies, such as affirmative action and immigration reform, to assure that they have equal opportunities and fair compensation in employment (Parrott 2014).

Paid parental leave would also help reduce gender differentiation in unpaid work by encouraging men to take longer leaves and form active fathering patterns. Unpaid parental leave has been described as "irrelevant" to men, as going without earnings for several weeks is not viewed as a legitimate option for most men (Singley and Hynes 2005, 393). Getting men to take paternity leave is important, as it provides time for men to develop greater confidence and skill in their own parenting (Coltrane 1996; Lamb 2004) and "challenges the perceived naturalness of women's superior parenting capabilities, and provid[es] men with time to develop a similar sense of parenting through hands-on experience" (Rehel 2014). Even though paternity leave may be for a relatively short period, it is argued to ultimately have a strong impact on the division of household labor by setting patterns at a critical time when household work is being renegotiated (Hook 2010; Kotsadam and Finseraas 2011; Pleck 1993). It also is believed to be beneficial for father-child relationships and child outcomes (Lamb 2004; O'Brien 2009; Pleck 1997). Due to these advantages, Quebec province in Canada and some European countries (notably the Nordic countries, Germany, Portugal, Slovenia, and Spain) have introduced non-transferable "daddy quotas," reserving a portion of a family's leave allotment for fathers only (Moss and Deven 2006; O’Brien 2013; Tremblay 2009). When combined with wage replacement, they seem especially powerful in encouraging men to use paternity leave, increasing gender parity in caring for young children, and lowering levels of conflict over the household division of labor (Hook 2010; Kotsadam and Finseraas 2011).

In addition to governmental and workplace policies, cultures of masculinity and adherence to ideal worker norms may also play an important role in affecting men's attitudes toward domestic work and physical caregiving (Coltrane 2000; Fried 1998; Gerson 2010; McGill 2014; Williams 1999). Cultural expectations shape how people expect new parents to behave, with bosses, co-workers, and friends sometimes discouraging men's active involvement in childrearing due to gendered assumptions about family and work (Coltrane 1996; Cowan and Cowan 2003; Pleck 1993). When the culture in the workplace discourages men from taking paternity leaves or utilizing flexible policies, even seemingly gender-neutral work-family policies shape men's and women's behaviors in different ways and reinforce gender differentiation during the transition to parenthood (Fried 1998; Rehel 2014). Challenging ideal worker norms, increasing cultural support for men's involved parenting, and improving the availability of compensated leaves for mothers and fathers would help decrease gender differentiation.

Couples-focused intervention programs that focus on improving both parenting (especially fathering) competence and partner awareness may also be helpful in navigating the 
difficulties related to the transition to parenthood, (Cowan et al. 2009; Doherty et al. 2006; Hawkins et al. 2008). While currently low-income or low-education couples are especially likely to be targeted for these programs due to higher levels of governmental intervention in poorer families, they could be useful more broadly. That many fathers don't feel confident in their abilities to care for a newborn is not surprising, as many men have limited exposure to infants prior to fatherhood (Lamb 2004). Unfortunately, this often acts as a barrier to father involvement (Cowan et al. 2009; Doherty et al. 2006; Hawkins et al. 2008).

Programs led by professionals that include multiple sessions across both the pre-partum and post-partum periods have been found to be most effective (Pinquart and Teubert 2010). Although it is reasonable to question whether programs like these are feasible to fund on a large scale, given the seriousness of the problems that many couples encounter during the transition to parenthood, there is a strong argument to be made for the continuing development of these programs and making them more widely available.

Finally, one important factor in how much time new mothers take off from work following the birth of their child is their ability to find suitable childcare and their feelings about using it (Barnes 2013; Stone 2007). The ongoing lack in the United States of high-quality affordable childcare and flexible policies to facilitate its usage means that many new parents find it difficult to effectively utilize paid providers for their young children (Gordon and Chase-Lansdale 2001; Pungello and Kurtz-Costes 1999; Stone 2007). Compared to other peer nations (for example, the developed nations that make up the Organisation for Economic Co-operation and Development), the United States has a much lower level of subsidizing childcare costs. Publically funded childcare programs are restricted to poor children (and often not available), while the majority of families receive assistance only indirectly though the child tax credit (Clawson and Gerstel 2007; Waldfogel 2001). The lack of public funding creates difficulties for parents because in most communities, a year of quality childcare costs more than a year of tuition at a public university (Clawson and Gerstel 2007).

The substantial financial cost and perceived lack of available childcare affect women in different ways depending on their social location. For low-income families and single mothers, a lack of stable childcare arrangements and other childcare challenges can serve as a significant barrier to maintaining stable paid employment (Bainbridge, Meyers, and Waldfogel 2003; Forry and Hofferth 2011). Policies that could reduce formal childcare costs and increase their availability would have a large positive effect on their employment (Han and Waldfogel 2001). Minority women are often faced with similar problems, as they are more likely than White women to attempt to resolve childcare demands through receiving practical childcare assistance from extended family members (Sarkisian and Gerstel 2004; Uttal 1999). Middle- and upper-class women in the paid labor force, who are positioned in high-intensity professional salaried positions, feel significant pressure (structurally and culturally) to resolve childcare dilemmas by temporarily "opting out" of the labor force (Stone 2007). Yet once they have left the paid labor market, they often have unanticipated difficulties returning when their children are older (Stone 2007). Clearly, this decision affects their individual advancement opportunities - and the advancement of women as a group. Greatly increasing the number of subsidized childcare centers available, loosening the guidelines for which children are eligible, and increasing the average quality of childcare centers would help resolve the work-family conflicts that many new parents face and decrease the gender inequity that arises during the transition to parenthood.

\section{Directions for future research}

In the last few decades, as work-family literature has become more global, awareness of cross-national research on the transition to parenthood has also increased. The majority of 
cross-national research on household labor has found that women still do more childcare and housework, although men have shown modest increases in unpaid work since the 1990s with significant variations existing by country (Cooke and Baxter 2010; Davis and Greenstein 2004; Hook 2006, 2010; Sayer 2010; Sayer and Gornick 2011; Treas and Drobnic 2010). Continued attention within the transition to parenthood literature on how experiences vary by country has great potential for future research, as it provides opportunities for examining the effects of disparate governmental policies, workplace organizations, and cultural ideas about parenting.

Gradually, researchers examining the transition to parenthood have paid better attention to the nuances of race, class, sexuality, and family structure. Nevertheless, as US families have increasingly become diverse, additional in-depth research is needed that takes an intersectional approach and considers additional groups. The number of White, middle-class married couples is shrinking, yet this is the group that we continue to know most about. Some families for whom we have considerably less knowledge regarding their transition to parenthood include live-apart parents, blended families, adoptive parents, gay fathers, and parents of varying immigrant statuses. Scholars have lately done a better job of including racially diverse samples, although they are not always adequate to analyze racial differences. A few recent studies have examined the division of paid and unpaid labor by racial-ethnic group (Parrott 2014; Sayer and Fine 2011; Wight et al. 2013), but additional in-depth investigations of other elements of the transition to parenthood are needed.

In addition to researching previously under-examined populations and continuing to develop new theories, it is important that scholars continue to revisit earlier questions with new cohorts of parents. Important studies of parents from two decades ago found that the division of baby care often ends up being more traditional than either partner expected (Cowan and Cowan 1992; Walzer 1998). We know that couples having children today are different than previous cohorts in their gender ideologies, work-family attitudes, parenting pressures, and relationship structure (Galinsky et al. 2009; Kluwer 2010; Parker and Wang 2013). The world has changed both economically and culturally. How do all of these changes affect how "millennial" couples make choices and how they feel about them? Most scholars appreciate the importance of cohort change, but its significance cannot go unstated. There is hope that recent developments in research methods, such as using longitudinal dyadic approaches or including similar groups of non-parents as a control, may help researchers understand the multiple and complex ways the transition to parenthood affects the life of new parents.

Scholars interested in the transition to parenthood have produced large amounts of research documenting how and why gender differentiation occurs among new parents. As societal changes continue to alter the landscape in which new parents negotiate one of life's most difficult transitions, scholars will no doubt build on the studies discussed here and continue examining the structures, cultures, and interaction patterns that affect them.

\section{Short Biography}

Medora Barnes' research is located at the intersection of family, gender, and work during the transition to parenthood. Her recent research has examined how women make maternity leave decisions based on a combination of parental leave policies, available childcare, and the gendered nature of their parenting ideologies. Other research topics include cultures of motherhood and fatherhood, marriage, pregnancy, and new reproductive technologies. In addition to presenting nationwide, some recent publications include articles in the Journal of Family Issues, Qualitative Sociology Review, and Journal of Consumer Culture. Dr. Barnes is currently 
an Assistant Professor of Sociology at John Carroll University (Cleveland, OH). She received her BA in Sociology from Trinity College (Hartford, CT) and PhD in Sociology from the University of Connecticut.

\section{Notes}

^ Correspondence address: Medora W. Barnes, Department of Sociology, John Carroll University, 1 John Carroll Blvd. University Heights, OH 44118, USA. E-mail: mbarnes@jcu.edu

1 The FMLA only covers employers with 50 or more workers. To be eligible, workers have to be full time and have worked for the company for 6 months. Due to these conditions, research has estimated that only a little more than half the workforce is covered (Armenia et al. 2014; Commission on Leave 1996).

2 Most state programs are types of Temporary Disability Insurance programs that provide short-term partially paid leaves for a variety of reasons, including pregnancy and childbirth. For an overview of the state laws, see Expecting Better: A State-by-State Analysis of Laws that Helps New Parents, 3rd edition, June 2014, National Partnership for Women and Families. Download at: http://www.nationalpartnership.org/research-library/work-family/expecting-better-2014.pdf

\section{References}

Allen, Sarah and Alan Hawkins. 1999. 'Maternal Gatekeeping: Mothers' Beliefs and Behaviors that Inhibit Greater Father Involvement in Family Work.' Journal of Marriage and Family 61(1): 199-212.

Armenia, Amy, Naomi Gerstel and Coady Wing. 2014. 'Workplace Compliance With the Law: The Case of the Family and Medical Leave Act.' Work and Occupations 41(3): 277-304.

Bainbridge, Jay, Marcia Meyers and Jane Waldfogel. 2003. 'Child Care Policy Reform and the Employment of Single Mothers.' Social Science Quarterly 84: 771-791.

Barnes, Medora. 2013. 'Having a First versus a Second Child: Comparing Women's Maternity Leave Choices and Concerns.' Journal of Family Issues 34(1): 85-112.

Baxter, Janeen, Belinda Hewitt and Michele Haynes. 2008. 'Life Course Transitions and Housework: Marriage, Parenthood, and Time on Housework.' Journal of Marriage and Family 70(2): 259-72.

Becker, Gary. 1981. A Treatise on the Family. Cambridge, MA: Harvard University Press.

Beitel, Ashley H., and Ross D. Parke. 1998. 'Paternal Involvement in Infancy: The Role of Maternal and Paternal Attitudes.' Journal of Family Psychology 12(2): 268-288.

Belsky, Jay and John Kelly. 1994. The Transition to Parenthood: How a First Child Changes a Marriage. New York: Delacorte Press.

Bianchi, Suzanne M., Melissa Milkie, Liana Sayer and John Robinson. 2000. 'Is Anyone Doing Housework? Trends in the Gender Division of Household Labor.' Social Forces 79(1): 191-228.

Bianchi, Suzanne M., Melissa Milkie, Liana Sayer and John Robinson. 2012. 'Housework: Who Did, Does or Will Do It, and How Much Does It Matter?' Social Forces 91(1): 55-63.

Bonnar, Deanne. 1991. 'The Place of Caregiving Work in Industrial Societies.' Pp. 192-206 in Parental Leave and Child Care, edited by Janet S. Hyde and Marilyn J. Essex. Philadelphia: Temple University Press.

Brayfield, April. 1995. 'Juggling Jobs and Kids.' Journal of Marriage and Family 57: 321-32.

Brines, Julie. 1993. 'The Exchange Value of Housework.' Rationality and Society 5(3): 302-40.

Budig, Michelle J. and Melissa J. Hodges. 2010. 'Differences in Disadvantage: Variation in the Motherhood Penalty across White Women's Earnings Distribution.' American Sociological Review 75(5): 705-728.

Carrington, Christopher. 1999. No Place Like Home: Relationships and Family Life among Lesbians and Gay Men. Chicago: University of Chicago Press.

Chodorow, Nancy. 1978. The Reproduction of Mothering. Berkeley: University of California Press.

Clawson, Dan and Naomi Gerstel. 2007. 'Caring for our young: Child care in Europe and in the United States.' Pp. 726-734. in Shifting the Center: Understanding Contemporary Families, edited by Susan Ferguson. Boston: McGraw Hill.

Cohany, Sharon and Emy Sok. 2007. Trends in Labor Force Participation of Married Mothers of Infants. Monthly Labor Review, Division of Labor Force Statistics, Bureau of Labor Statistics.

Coltrane, Scott. 1989. 'Household Labor and the Routine Production of Gender.' Social Problems 36: 473-490.

Coltrane, Scott. 1996. Family Man: Fatherhood, Housework and Gender Equity. New York: Oxford University Press.

Coltrane, Scott. 2000. 'Research on Household Labor: Modeling and Measuring the Social Embeddedness of Routine Family Work.' Journal of Marriage and Family 62: 208-33. 
Commission on Leave. 1996. A Workable Balance: Report to Congress on Family and Medical Leave Policies. Washington, DC: U.S. Department of Labor.

Cooke, Lynn P. and Janeen Baxter. 2010. “"Families” in International Context: Comparing Institutional Effects across Western Societies.' Journal of Marriage E Family 72: 516-36.

Correll, Shelley, Stephen Bernard and In Paik. 2007. 'Getting a Job: Is There a Motherhood Penalty?' American Journal of Sociology 112: 1297-338.

Coverman, Shelley. 1985. 'Explaining Husbands' Participation in Domestic Labor.' The Sociological Quarterly 26(1): 81-97.

Cowan, Carolyn Pape and Philip A. Cowan. 1992. When Partners Become Parents: The Big Life Change for Couples. New York: Basic Books.

Cowan, Carolyn Pape and Philip A. Cowan. 2003. 'New Families: Modern Couples as New Pioneers.' Pp. $244-264$ in All Our Families: New Policies for a New Century, edited by Mary Ann Mason, Arlene Skolnick and Stephen Sugarman. New York: Oxford University Press.

Cowan, Philip A., Carolyn Pape Cowan, Marsha Kline Pruett, Kyle Pruett and Wong, Jessie J. 2009. 'Promoting Fathers' Engagement with Children: Preventive Interventions for Low-income Families.' Journal of Marriage and Family 71: $663-679$.

Cox, Martha J., Blair Paley, Margaret Burchinal and C. Chris Payne. 1999. 'Marital Perceptions and Interactions across the Transition to Parenthood.' Journal of Marriage and the Family 61(3): 611-625.

Davis, Shannon N. and Theodore N. Greenstein. 2004. 'Cross-national Variations in the Division of Household Labor.' Journal of Marriage and Family 66(5): 1260-1271.

Davis, Shannon N., Theodore N Greenstein and Jennifer P. Gerteisen Marks. 2007. 'Effects of Union Type on Division of Household Labor.' Journal of Family Issues 28(9): 1246-1272.

Deutsch, Francine M., Julianne B. Lussier and Laura Servis. 1993. 'Husbands at Home: Predictors of Paternal Participation in Childcare and Housework.' Journal of Personality and Social Psychology 65: 1154-1166.

DeVault, Marjorie L. 1991. Feeding the Family: The Social Organization of Caring as Gendered Work. Chicago: University of Chicago Press.

Dew, Jeffery and W. Bradford Wilcox. 2011. 'If Momma Ain't Happy: Explaining Declines in Marital Satisfaction among New Mothers.' Journal of Marriage and Family 73: 1-12.

Doherty, William J., Martha Farrell Erickson and Ralph LaRossa. 2006. 'An Intervention to Increase Father Involvement and Skills with Infants during the Transition to Parenthood.' Journal of Family Psychology, 20: 438-447.

Doucet, Andrea. 2006. Do Men Mother? Fathering, Care and Domestic Responsibility. Toronto: University of Toronto Press.

Dunne, Gillian. 2000. 'Opting into Motherhood: Lesbians Blurring the Boundaries and Transforming the Meaning of Parenthood and Kinship.' Gender and Society 14(1): 11-35.

Ehrensaft, Diane. 1990. Parenting Together: Men and Women Sharing the Care of Their Children. Urbana, IL: University of Illinois Press.

England, Paula. 2005. 'Gender Inequality in Labor Markets: The Role of Motherhood and Segregation.' Social Politics 12(2): 264-88.

Ferree, Myra Marx. 1990. 'Beyond Separate Spheres: Feminism and Family Research.' Journal of Marriage and the Family 52: 866-884.

Forry, Nicole and Sandra L. Hofferth. 2011. 'The Influence of Child Care Subsidies on Child Care-related Work Disruptions.' Journal of Family Issues 32(3): 346-368.

Fox, Bonnie. 2009. When Couples Become Parents: The Creation of Gender in the Transition to Parenthood. Toronto: University of Toronto Press.

Fried, Mindy. 1998. Taking Time: Parental Leave Policy and Corporate Culture. Philadelphia: Temple University Press.

Galinsky, Ellen, Kerstin Aumann, James T. Bond. 2009. Times Are Changing: Gender and Generation at Work and Home. Families and Work Institute. Retrieved from: http://familiesandwork.org/site/research/reports/Times_Are_Changing.pdf

Garey, Anita Ilta. 1999. Weaving Work and Motherhood. Philadelphia: Temple University Press.

Gaunt, Ruth. 2006. 'Biological Essentialism, Gender Ideologies, and Role Attitudes: What Determines Parents' Involvement in Child Care.' Sex Roles 55(7-8): 523.

Gaunt, Ruth. 2008. 'Maternal Gatekeeping: Antecedents and Consequences.' Journal of Family Issues 29: 373-95.

Gerson, Kathleen. 1993. No Man's Land: Men's Changing Commitments to Family and Work. New York: Basic Books.

Gerson, Kathleen. 2010. The Unfinished Revolution: How a New Generation Is Reshaping Family, Work, and Gender in America. New York, NY: Oxford University Press.

Gjerdingen, Dwenda K. and Bruce A. Center. 2004. 'First Time Parents' Postpartum Changes in Employment, Childcare, and Housework Responsibilities.' Social Science Research 34: 103-116.

Glass, Jennifer. 1998. 'Gender Liberation, Economic Squeeze, or Fear of Strangers: Why Fathers Provide Infant Care in Dual-earner Families.' Journal of Marriage and the Family 60(4): 821-34. 
Glass, Jennifer and Tutsushi Fujimoto. 1994. 'Housework, Paid Work, and Depression among Husbands and Wives.' Journal of Health and Social Behavior 35: 179-191.

Goffman, Erving. 1977. 'The Arrangement between the Sexes.' Theory and Society 4(3): 301-331.

Goldberg, Abbie E. and Maureen Perry-Jenkins. 2007. 'The Division of Labor and Perceptions of Parental Roles: Lesbian Couples across the Transition to Parenthood.' Journal of Social and Personal Relationships 24: 297-318.

Goldberg, Abbie E., Julianna Z. Smith and Maureen Perry-Jenkins. 2012. 'The Division of Labor in Lesbian, Gay, and Heterosexual New Adoptive Parents.' Journal of Marriage and Family 74: 812-828.

Gordon, Rachel A. and P. Lindsay Chase-Lansdale. 2001. 'Availability of Child Care in the United States: A Description and Analysis of Data Sources.' Demography 38(2): 299-316.

Gornick, Janet. 2000. 'Family Policy and Mothers' Employment: Cross-national Variations.' Pp. 97-120 in Gender, Welfare State and the Market, edited by Thomas Boje and Arnlaug Leira. London: Routledge.

Gornick, Janet and Marcia Meyers. 2009. Gender Equality: Transforming Family Divisions of Labor. Verso: New York, NY.

Gornick, Janet C., Marcia K. Meyers and Katherin E. Ross. 1998. 'Public Policies and the Employment of Mothers: A Cross-national Survey.' Social Science Quarterly 79(1): 35-54.

Gouch, Mararet and Mary Noonan. 2013. 'A Review of the Motherhood Wage Penalty in the United States.' Sociology Compass 7(4): 328-342.

Han, Wenjui and Jane Waldfogel. 2001. 'Child Care Costs and Women's Employment: A Comparison of Single and Married Mothers with Pre-school-aged Children.' Social Science Quarterly 82(3): 552-568.

Hartmann, Heidi and Vicky Lovell. 2009. 'A US model of Universal Sickness and Family Leave.' Pp. 231-251 in Gender Equality: Transforming Family Divisions of Labor, edited by Janet Gornick and Marcia Meyers. New York, NY: Verso.

Hawkins, Alan J., Kimberly R. Lovejoy, Erin. K. Holmes, Victoria Blanchard and Elizabeth Fawcett. 2008. 'Increasing Fathers' Involvement in Child Care with a Couple Focused Intervention during the Transition to Parenthood.' Family Relations 57: 49-59.

Hays, Sharon. 1996. The Cultural Contradictions of Motherhood. New Haven, CT: Yale University Press.

Helms-Erikson, Heather. 2001. 'Marital Quality Ten Years after the Transition to Parenthood: Implications of the Timing of Parenthood and the Division of Housework.' Journal of Marriage and Family 63: 1099-1110.

Hochschild, Arlie. 1983. The Managed Heart: Commercialization of Human Feeling. Berkeley, CA: University of California Press.

Hochschild, Arlie Russell. 1989. The Second Shift: Working Parents and the Revolution at Home. New York: Viking.

Hofferth, Sandra L. 1996. 'Effects of Public and Private Policies on Working after Childbirth.' Work and Occupations 23 (4): 378-404.

Hook, Jennifer L. 2006. 'Care in Context: Men's Unpaid Work in 20 Countries, 1965-2003.' American Sociological Review 71: 639-60.

Hook, Jennifer L. 2010. 'Gender Inequality in the Welfare State: Sex Segregation in Housework, 1965-2003.' American Journal of Sociology 115(5): 1480-1523.

Jacobs, Jerry, and Kathleen, Gerson. 2004. The Time Divide: Work, Family, and Gender Inequality. Cambridge, MA: Harvard University Press.

Joesch, Jutta M. 1997. 'Paid Leave and Timing of Women's Employment before and after Birth.' Journal of Marriage and the Family 59 (4): 1008-21.

Kaufman, Gayle, and Peter Uhlenberg. 2000. 'The Influence of Parenthood on the Work Effort of Married Men and Women.' Social Forces 78 (3): 931-47.

Keizer, Renske and Niels Schenk. 2012. 'Becoming a Parent And Relationship Satisfaction: A Longitudinal Dyadic Perspective.' Journal of Marriage and Family 74: 759-773.

Kluwer, Esther S. 2010. 'From Partnership to Parenthood: A Review of Marital Change across the Transition to Parenthood.' Journal of Family Theory \& Review 2: 105-125.

Kluwer, Esther S., Heesink José A. M. and Evert Van De Vliert. 1996. 'Marital Conflict about the Division of Household Labor and Paid Work.' Journal of Marriage and the Family 58: 958-969.

Kluwer, Esther S., Heesink, José A. M. and Evert, Van De Vliert. 2002. 'The Division of Labor across the Transition to Parenthood: A Justice Perspective.' Journal of Marriage and Family 64: 930-943.

Kotsadam, Andreas and Henning Finseraas. 2011. 'The State Intervenes in the Battle of the Sexes: Causal Effects of Paternity Leave.' Social Science Research 40(6): 1611-1622.

Lamb, Michael. Ed. 2004. The Role of the Father in Child Development, (4th edn). New York: John Wiley and Sons.

Lareau, Annette. 2003. Unequal Childhoods: Class, Race and Family Life. Berkeley: University of California Press.

LaRossa, Ralph and Maureen Mulligan LaRossa. 1989. 'Baby Care: Fathers vs. Mothers.' Pp. 138-154 in Gender in Intimate Relationships: A Microstructural Approach, edited by Risman, Barbara J. and Schwartz Pepper. Belmont, CA: Wadsworth Publishing Company. LaRgssa, Ralph and Maureen Mulligan LaRossa. 1981. Transition to Parenthood: How Infants Change Families. Beverly Hills, 
Latshaw, Beth. 2011. 'The More Things Change, the More They Remain the Same? Paradoxes of Men's Unpaid Labor Since "The Second Shift”.' Sociology Compass 5(7): 653-665.

Laughlin, Lynda. 2011. 'Maternity Leave and Employment Patterns of First-time Mothers: 1961-2008.' Current Population Reports, pp 70-128, United States Census Bureau. Washington, D.C.

McGill, Brittany S. 2014. 'Navigating New Norms of Involved Fatherhood: Employment, Fathering Attitudes, and Father Involvement.' Journal of Family Issues 35(8): 1089-1106.

Meteyer, Karen and Maureen Perry-Jenkins. 2010. 'Father Involvement among Working-class, Dual-earner Couples.' Fathering 8(3): 379-403.

Milkie, Melissa A. 2011. 'Social and Cultural Resources for and Constraints on New Mothers' Marriages.' Journal of Marriage and Family 73: 18-22.

Milkie, Melissa A., Sara B. Raley, and Suzanne M. Bianchi. 2009. 'Taking on the Second Shift: Time Allocations and Time Pressures of US Parents with Preschoolers.' Social Forces 88: 487-517.

Moss, Peter, and Fred Deven. 2006. 'Leave Policies and Research: A Cross-national Overview.' Marriage E Family Review 39: 255-285.

Nelson, Margaret K. 2010. Parenting out of Control: Anxious Parents in Uncertain Times. New York: New York University Press.

O’Brien, Margaret. 2009. 'Fathers, Parental Leave Policies and Infant Quality of Life: International Perspectives and Policy Impact.' The Annals of the American Academy of Political and Social Science 624(1): 190-213.

O'Brien, Margaret. 2013. 'Fitting Fathers into Work-Family Policies: International Challenges in Turbulent Times.' International Journal of Sociology and Social Policy 33(9/10): 542-564.

Oliker, Stacey. 2011. 'Sociology and Studies of Gender, Caregiving, and Inequality.' Sociology Compass 5(11): $968-983$.

Parker, Kim and Wendy Wang. 2013. 'Modern Parenthood: Roles of Moms and Dads Converge as They Balance Work and Family.' Washington, D.C.: Pew Research Center.

Parrott, Heather Macpherson. 2014. "Housework, Children, and Women’s Wages Across Racial-Ethnic Groups." Social Science Research 46:72-84.

Parsons, Talcott and Robert F. Bales. 1955. Family, Socialization, and Interaction Process. Glenco, ILL.: Free Press.

Pinquart, Martin and Daniela Teubert. 2010. 'A Meta-analytic Study of Couple Interventions during the Transition to Parenthood.' Family Relations 59: 221-231.

Pleck, Joseph. 1993. 'Are “Family-supportive” Employer Policies Relevant to Men?’ Pp. 217-237 in Men, Work and Family, edited by Jane C. Hood. Newbury Park, CA: Sage.

Pleck, Joseph H. 1997. 'Paternal Involvement: Levels, Sources, and Consequences.' Pp. 66-103 in The Role of the Father in Child Development, edited by Michael E. Lamb. New York: John Wiley and Sons.

Pungello, Elizabeth Puhn and Beth Kurtz-Costes. 1999. 'Why and How Working Women Choose Child Care: A Review with a Focus on Infancy.' Developmental Review 19: 31-96.

Raley, Sara, Suzanne M. Bianchi and Wendy Wang. 2012. 'When Do Fathers Care? Mothers' Economic Contribution and Fathers' Involvement in Childcare.' American Journal of Sociology 117(5): 1422-1459.

Rehel, Erin M. 2014. 'When Dad Stays Home Too: Paternity Leave, Gender, and Parenting.' Gender E Society 28(1): 110-132.

Reimann, Renate. 1997. 'Does Biology Matter? Lesbian Couples' Transition to Parenthood and Their Division of Labor.' Qualitative Sociology 20(2): 153-185.

Risman, Barbara J. 1998. Gender Vertigo: American Families in Transition. New Haven, CT: Yale University Press.

Robinson, John P. and Geoffrey Godbey. 1999. Time for Life. University Park, Pennsylvania: Pennsylvania State University Press.

de Ruijter, Esther, Judith Treas and Philip Cohen. 2005. 'Outsourcing the Gender Factory.' Social Forces 84(1): 305-22.

Sanchez, Laura and Elizabeth Thomson. 1997. 'Becoming Mothers and Fathers: Parenthood, Gender, and the Division of Labor.' Gender \& Society 11(6): 747-72.

Sarkisian, Natalia and Naomi Gerstel. 2004. 'Kin Support among Blacks and Whites: Race and Family Organization.' American Sociological Review 69: 812-837.

Sayer, Liana C. 2005. 'Gender, Time, and Inequality: Trends in Women's and Men's Paid Work, Unpaid Work, and Free Time.' Social Forces 84: 285-303.

Sayer, Liana C. 2010. 'Trends in Housework.' Pp. 19-38 in Dividing the Domestic: Men, Women, and Household Work in Crossnational Perspective, edited by Judith Treas and Sonja Drobnic. Stanford: Stanford University Press.

Sayer, Liana C. and Leigh Fine. 2011. 'Racial-Ethnic Differences in US Married Women's and Men's Housework.' Social Indicators Research 101(2): 259-265.

Sayer, Liana C. and Janet C. Gornick. 2011. 'Cross-national Variation in the Influence of Employment Hours on Child Care Time.' European Sociological Review 28(4):421-442.

Schor, Juliet B. 1991. The Overworked American: The Unexpected Decline of Leisure. New York: Basic Books.

Shelton, Beth and Daphne John. 1996. 'The Division of Household Labor.' Annual Review of Sociology 22: $299-322$. 
Shows, Carla and Naomi Gerstel. 2009. 'Fathering, Class, and Gender: A Comparison of Physicians and Emergency Medical Technicians.' Gender \& Society 23:161-87.

Singley, Susan G. and Kathryn Hynes. 2005. 'Transitions to Parenthood: Work-Family Policies, Gender, and the Couple Context.' Gender and Society 19(3): 376-397.

Steil, Janice M. 1997. Marital Equality: Its Relationship to the Well-being of Husbands and Wives. Thousand Oaks, CA: Sage Publications.

Stone, Pamela. 2007. Opting Out? Why Women Really Quit Careers and Head Home. Berkeley: University of California Press. Sullivan, Oriel. 2013. 'What Do We Learn about Gender by Analyzing Housework Separately from Child Care? Some Considerations from Time-use Evidence.' Journal of Family Theory \& Review 5: 72-84.

Taylor, Verta. 1996. Rock-a-by Baby: Feminism, Self-help, and Postpartum Depression. New York: Routledge.

Treas, Judith and Sonja Drobnic (eds). 2010. Dividing the Domestic: Men, Women, and Household Work in Cross-national Perspective. Stanford: Stanford University Press.

Tremblay, Diane-Gabrielle. 2009. ‘Quebec's Policies for Work-Family Balance: A Model for Canada?’ Pp. 271-290 in Public Policy for Women: The State, Income Security, and Labour Market Issues, edited by Marjorie G. Cohen and Jane Pulkingham. Toronto: University of Toronto Press.

Upton, Rebecca L. 2000. The Next One Changes Everything: Parental Adjustment to the Second Child Among Middle-class American Families. A Working Paper for The Center for the Ethnography of Everyday Life: An Alfred P. Sloan Center for the Study of Working Families.

Uttal, Lynet, 1999. 'Using Kin for Child Care: Embedment in the Socioeconomic Networks of Extended Families.' Journal of Marriage and Family 61: 845-857.

Waldfogel, Jane. 1998. 'Understanding the "Family Gap" in Pay for Women with Children.' Journal of Economic Perspectives 12 (1): 137-56.

Waldfogel, Jane. 2001. 'International Policies Toward Parental Leave and Child Care.' The Future of Children 11(1): 99-111.

Walzer, Susan. 1998. Thinking about the Baby: Gender and Transitions into Parenthood. Philadelphia, PA: Temple University Press.

West, Candace and Don H. Zimmerman. 1987. 'Doing Gender.' Gender E Society 1: 125-51.

Wharton, Amy S. 2012. 'Work and Family in the 21st Century: Four Research Domains.' Sociology Compass 6(3): $219-235$.

Wight, Vanessa R., Suzanne M. Bianchi and Bijou R. Hunt. 2013. 'Explaining Racial/Ethnic Variation in Partnered Women's and Men's Housework: Does One Size Fit All?' Journal of Family Issues 34: 394-427.

Williams, Joan. 1999. Unbending Gender: Why Work and Family Conflict and What to Do about It. New York: Oxford University Press. 